\title{
₹USGS
}

science for a changing world

\section{Hydrogeologic Factors that Influence Ground Water Movement in the Desert Southwest United States}

By Frank C. Chuang, Edwin H. McKee, and Keith A. Howard

Open-File Report 03-294

Version 1.0

2003

This report is preliminary and has not been reviewed for conformity with U.S. Geological Survey editorial standards or with the North American Stratigraphic Code. Any use of trade, product, or firm names is for descriptive purposes only and does not imply endorsement by the U.S. Government.

\section{U.S. DEPARTMENT OF THE INTERIOR U.S. GEOLOGICAL SURVEY \\ Menlo Park, California 94025}




\section{INTRODUCTION}

A project to study ground-water and surface-water interactions in the desert southwestern United States was initiated in 2001 by the Tucson, Arizona office of the Water Resources Division, U.S. Geological Survey (USGS). One of the goals of the Southwest Ground-water Resources Project was to develop a regional synthesis that includes the use of available digital geologic data, which is growing rapidly due to the increasing use of Geographic Information Systems (GIS). Included in this report are the digital maps and databases of geologic information that should have a direct impact on the studies of ground-water flow and surface-water interaction.

Ground-water flow is governed by many geologic factors or elements including rock and soil permeability, stratigraphy and structural features. These elements directly influence ground-water flow, which is key to understanding the possible interconnectivity of aquifer systems in desert basins of the southwestern United States. We derive these elements from the evaluation of regional geology and localized studies of hydrogeologic basins. These elements can then be applied to other unstudied areas throughout the desert southwest. This report presents a regional perspective of the geologic elements controlling ground-water systems in the desert southwest that may eventually lead to greater focus on smaller sub-regions and ultimately, to individual ground-water basins.

\section{HYDROGEOLOGIC FRAMEWORK - DESERT SOUTHWEST (DSW)}

The first part of the project was concerned with the movement of ground-water in the Great Basin of the western United States. Howard and others (2003) gathered information from many regional and local studies published in the last two decades to highlight geologic data that could address these concerns. Many of the concepts developed in that study may apply to other parts of the desert southwest (DSW) - especially in regions where the paleotectonic evolution is similar to the Great Basin. The DSW comprises the Basin and Range physiographic province and parts of adjacent provinces (see Index Sheet). The geologic history of the region dictates the sedimentary and structural framework that, in turn, controls ground-water movement in local areas.

In this study, we have taken geologic data from state geologic maps to develop a series of digital hydrogeologic maps which are used to evaluate the elements that can be expected to influence ground-water regimes in different parts of the DSW. The unconsolidated, consolidated, and lithified units used in this study were made by combining appropriate geologic units from digitized state maps of Arizona, California, Colorado, Idaho, Nevada, New Mexico, Oregon, and Utah (see Appendix). The statewide hydrogeologic units derived from these sources, merge at the state boundaries with good agreement. A geohydrologic map of the entire region (Sheet 1) groups multiple geologic units having similar hydrologic properties into hydrogeologic units. The first nine element maps (Sheets 2-10) portray each of the hydrogeologic map units in the entire region. Overall, a total of fifteen elements are identified and plotted on separate maps (Sheets 2-16) that can be combined (by computer or manually) to show which combinations of elements are present in different parts of the DSW. Some areas may contain all 15 elements, other areas may contain any number of element combinations. 
The elements represent the first approximation of the expected hydrogeologic setting of a sub-area within the DSW. This setting can then be a guide to more detailed local studies including field observations.

To give the dimension of time and tie the most recent geologic history of the southwestern U.S. to some of the elements, five interpretative paleotectonic maps at varying time intervals in the Cenozoic are presented (Sheets 17-21). These paleotectonic maps indicate where and when different geologic landscapes existed in the last 55 million years. The landscape in turn controlled the type and accumulation of sediments in the DSW as well as where older (pre-Cenozoic) rocks were exposed by erosion. Included on the paleotectonic maps are the volcanic rocks that were erupted at different places and times during Cenozoic time.

We have also portrayed the dimension of time in a non-map-based format as shown on Table 1. With geologic time represented along the vertical axis and geographic location along the horizontal axis, the various lithologic, stratigraphic, and structural elements that govern ground-water flow can be evaluated with respect to each other in time and space.

\section{Hydrogeologic elements}

The fifteen hydrogeologic elements (Sheets 2-16) selected to have the greatest influence on ground-water systems in the DSW can be divided into five groups related to geologic parameters. [1] Unconsolidated to compacted and consolidated younger sediment mostly of Quaternary age (Sheet 2), and older Cenozoic sedimentary rocks, (Sheets 3, 4); [2] lithified material, including basaltic rocks of Cenozoic age (Sheet 5), volcanic rocks of Cenozoic age (Sheet 6), crystalline rocks including granitoids, gneisses and schists ( mostly older than Cenozoic) (Sheet 7), siliceous and carbonate sedimentary rocks mostly of pre-Cenozoic age (Sheets 8, 9, 10); [3] areas of regional alteration (Sheet 11); [4] basins containing a variety of unlithified fill, lithified fill, and geometries (Sheets 12, 13); [5] tectonic-structural features (Sheets 14, 15, 16).

Unocnsolidated alluvial deposits (Sheet 2). Surficial deposits mostly of Quaternary age forming extensive tracts of permeable material at or near the surface throughout the DSW. These deposits include widespread alluvial fans that flank the mountains and extend into the basins where they intertongue with finer-grained fluvial and lacustrine sediments and local playa deposits. The deposits may be thousands of feet thick in the deeper basins where they merge with older Cenozoic sedimentary rocks. The coarsergrained, poorly- sorted, non-lithified sediments form aquifers. The finer-grained sediments may restrict water flow, but the unconsolidated alluvial deposits, as a group, generally form aquifers.

Older basin-fill deposits, coarse to fine- grained (Sheet 3), or fine-grained (Sheet 4)). Tertiary deposits of indurated and lithified alluvial fan, lacustrine, and fluvial origin underlie many basins in the DSW. In most places these rocks are concealed by Quaternary sedimentary deposits, however, they merge with these deposits at shallower depths in the alluvial basins. Older basin-fill deposits are exposed where erosion has dissected the basin and as isolated local outcrops in the surrounding mountains. The total 
thickness of the older basin-fill, plus the overlying unconsolidated alluvium and other local Cenozoic volcanic rocks can be more than 10,000 feet as indicated by maps from gravity inversion modeling that distinguish lower density basin-fill from higher density pre-Cenozoic basement (Saltus, 1988; Jachens and others, 1996). The sand and gravel beds in these basin-fill deposits are permeable, but the finer-grained units are less permeable and tend to restrict water flow. In general, the older basin-fill sequences with their lenticular alluvial fan and fluvial sand and gravel beds act as aquifers on a regional scale.

Cenozoic basaltic rocks (Sheet 5). Basaltic rocks mostly Quaternary and Neogene lava flows and local dikes, underlie and crop out in large areas within the DSW. Other rocks in this group includes small amounts of high-silica rhyolite as part of a bi-modal igneous suite. These high-silica rhyolites have similar hydro- transmissivity characteristics as the basalts. Although these volcanic rocks have little intergrain porosity, they typically contain many fractures rendering them permeable and transmissive to the flow of water. Basalt flows and dikes may locally block the flow of water but do not act as barriers on a regional scale. At the scale of the maps presented in this study $(1: 2,000,000)$ the basaltic rocks are considered aquifer units.

Cenozoic andesite, dacite, and rhyolitic, rocks (Sheet 6). Volcanic and shallow intrusive rocks of many petrochemical and lithologic types are widespread throughout the DSW. In this study, all of these rocks are considered as one hydrogeologic element separated from basaltic rocks that are classified as another element (see above). They are separated from the basaltic rocks because they include a much greater proportion of tuffs of all types than do the basalts that are represented mostly by lava flows. Lava flows and ash flow tuffs are the most widespread volcanic rocks in this general igneous group. Non-welded and welded rhyolite and dacite ash flows (welded tuff) cover hundreds of square miles in some parts of the Great Basin and the southeastern part of the Basin and Range Province. Rhyolite, dacite, and andesite lava flows are more local than ash flows but form extensive volcanic fields surrounding their vent volcanoes. Both lava flows and welded tuffs form non-porous rock that tends to be cracked and fractured leading to permeability along multiple fracture networks. Because of fracture flow these rock units are generally aquifers rather than hydrologic barriers. Volcanic mud-flows, agglomerates, and many volcanic ash deposits that form tuffs are susceptible to alteration forming various clay minerals and zeolites that render these otherwise permeable rocks impermeable. As a general hydrogeologic element in this study, the andesitic; dacitic; and rhyolitic rock category is considered to be mostly an aquifer.

Crystalline rocks (Sheet 7). Metamorphic and intrusive igneous rocks have similar hydrologic properties and are combined here as a single hydrogeologic element. These rocks are predominantly pre-Cenozoic in age. The metamorphic rocks include gneisses, schists, and granitoids of Precambrian age and granitoid batholiths and plutons that are mostly Mesozoic in age, and some smaller granitic and dioritic intrusive bodies of Cenozoic age. The homogeneous, dense, interlocking crystalline nature of these rocks produce a hydrologic barrier in most cases. The crystalline rocks in the DSW are considered here as aquitard or flow- barrier units. 
Siliceous sedimentary rocks-- coarse-grained (Sheet 8). Sandstone (including quartzite) and quartzose conglomerate of pre-Cenozoic age constitute this hydrogeologic element. This type of rock is entirely clastic and previous studies have referred to it as clastic (Winograd and Thordarson, 1975), as siliceous clastic (McKee, 1997), or as a quartzite confining unit (Laczniak and others, 1996). Here we distinguish grain size, which is an important permeability factor, and emphasize siliceous composition in contrast to clastic carbonate rocks. Fine-grained siliceous and all carbonate rocks are separate elements in this study (see below). The coarse-grained siliceous rocks have variable hydrologic properties depending on grain sorting, compaction, cementation, recrystallization, and fracturing. In general they act as aquifers on a regional scale because the weakly compacted, poorly cemented types are porous whereas the tightly compacted, cemented, and recrystallized types such as quartzites develop fractures that serve as hydrologic pathways. If the fracture system is blocked by secondary fracture filling or by recrystallization the siliceous rock may revert to being a flow barrier.

Siliceous sedimentary rocks-fine-grained (Sheet 9). Siltstone, mudstone, claystone, chert, and argillite of pre-Cenozoic age form a subgroup of rocks called clastic (Winograd and Thordarson, 1975) and siliceous clastic (McKee, 1997). These rocks act as aquitards or hydrologic confining units in most places, and have low initial porosity and permeability. In addition, compaction and cementation make them even less porous and permeable. Fractures in these rocks tend to be filled by secondary mineralization and have healed. On a regional scale, these fine-grained siliceous sedimentary rocks are considered to be aquitards that restrict the flow of ground-water.

Carbonate rocks (Sheet 10). Limestone and dolostone mostly of pre-Cenozoic age constitute this hydrogeologic element. These carbonate rocks are thousands of feet thick in parts of the DSW, and are almost universally aquifers. Although not particularly porous rocks, limestones and dolostones tend to fracture easily and these fractures are enlarged by aqueous solution to form extensive ground-water flow systems. Locally, ancient buried karst topography and interconnecting solution caverns produce major underground flow paths. These rocks may form major regional aquifers (Winograd and Thordarson, 1975).

Regional-scale alteration (Sheet 11). Rock alteration can effect ground-water transmissivity in many ways. Cavity formation or enlargement by leaching may enhance permeability, but more often, recrystallization and cavity filling by secondary minerals decreases permeability. The formation of alteration minerals on a regional scale by diagenetic processes or the addition of new minerals from hydrothermal sources can disrupt or alter aquifer systems. The location of mineral deposits in the DSW (Long and others, 2000) was used as a guide to areas of rock alteration. Two mineral deposit types that are associated with alteration at a scale large enough to be compatible with the other hydrogeologic elements in this study are; [1] copper porphyry systems and [2] epithermal and hot-spring precious-metal systems. Large copper mines in the southern part of the Basin and Range province and a few places in the Great Basin are associated with widespread, pervasive potassic alteration characterized by secondary potassium feldspar, biotite, sericite, chlorite, quartz, kaolinite, montmorillinite, and sulfide minerals. This alteration and mineralization disrupts the regional aquifer systems and, in most places, retards and blocks the flow of ground-water. Precious metal deposits, in particular those 
related to epithermal- hot spring activity in the western part of the Great Basin, are part of large areas of prophyllitic and argillitic alteration, characterized by abundant secondary chlorite, calcite, clay minerals, zeolites, opaline silica, chert, and quartz. As with hydrothermal porphyry alteration and mineralization, these minerals formed in a epithermal setting and tend to change rock porosity, leading to a decrease in permeability.

Deep basins (Sheet 12). Basins containing low-density rocks and alluvium that are $1 \mathrm{~km}$ (3,280 ft.) or more thick, are defined using gravity-inversion techniques (Saltus, 1988; Saltus and Jachens, 1995; and Jachens and others, 1996). The gravity inversion models a 3 -dimensional surface between rocks with a specific gravity of $2.67 \mathrm{~g} / \mathrm{cm}^{3}$, considered to be pre-Cenozoic basement, and less dense rocks and alluvium (sp. gr. 1.9 to $2.45 \mathrm{~g} / \mathrm{cm}^{3}$ ), considered to be surficial cover and basin-fill. A thickness of $1 \mathrm{~km}$ or more of lowdensity material is used to define basins in the DSW because it highlights the areas of exceptionally thick, low-density material. The modeled surfaces show the significant basins and are distinguishable from buried pediments or other erosional bedrock surfaces. Viewing basins in this way shows a clear distinction between the northern (Great Basin) and southern (the Sonoran Desert and Mexican Highlands; see Index sheet) parts of the Basin and Range Province. The Great Basin has a number of generally linear northtrending basins reflecting the present Basin and Range topography. The Sonoran Desert and Mexican Highlands have fewer basins with no particular shape or preferred orientation. The distribution of basins is an important element for potential regional ground-water flow patterns. Because basin fill is generally permeable, basins act as aquifers or areas of subsurface water accumulation. If they are bounded or rimmed by impermeable rock such as dense fine-grained siltstone or argillite, the basin may act as a reservoir. Elsewhere where the bedrock is an aquifer type, such as limestone, the basin and its fill will be part of the through-going ground-water flow system.

Symmetry of basins (Sheet 13). The 3-dimensional shape of basins is important in analyzing ground-water flow through Cenozoic rocks that fill most basins in the DSW. The distribution, geometry, and lithology of rock units and the faults that bound the basins are the elements of the aquifers and aquitards in a ground-water system and reflect the tectonic and sedimentary history of the basin. Topography serves as a guide for two dimensions of the basin but gives little indication of the third dimension. Modeling by gravity- inversion techniques is used to define depth and shape of the buried part of the basin (third dimension) and from this analysis it is seen that many basins are asymmetrical with an irregular axial trough. We evaluate basins that have lateral dimensions at least six kilometers wide and ten kilometers long and a minimum of 1000 meters of fill (a depth to bedrock of $1 \mathrm{~km}$ or more) as determined by gravity-inversion. Most of these basins have a general northerly trend. Many large alluvium covered areas in the DSW that appear at the surface to be basins are not deep enough to qualify as basins by this measure. This is especially true of the southern part of the Basin and Range Province.

The 3-dimensional pattern of basin fill and ultimately the ground-water flow system in the basin will mirror the basin shape. Alluvial fan deposits adjacent to the edge of a deep basin grade into better sorted, finer-grained fluvial and lacustrine deposits in the axis of the basin, offer different transmissivity from each other and differ from mixed alluvial deposits that cloak bedrock pediments in shallow parts of the basin. Faults along the base 
of mountain ranges (horst and graben) bound many of the deeper basins in the Basin and Range province. The edges of the basin axial trough mark the location of the basin forming faults. In asymmetrical basins with the trough on the east or west side of the basin, the bounding fault system will likewise be on the opposite side of the basin. Fault related flow paths will be asymmetrically located with respect to the surface outline of the basin.

Cenozoic collapse calderas (Sheet 14). Collapse calderas of Cenozoic age occur at many places in the DSW and are especially abundant in the central part of the Great Basin (Best and others, 1989; McKee, 1996). These volcano/tectonic features are typically oval, $10 \mathrm{~km}$ or more in diameter, thousands of meters deep, and formed following the catastrophic eruption of silicic magma (mostly as ash) from a shallow magma chamber. The explosive eruption may have produced a crater but the major caldera formed by collapse of the surface rocks into the void created by the withdrawal of volcanic material from the chamber. Faulting caused by collapse is concentric and generally inwardly dipping but the system of faults is complex and variable. The topographic depressions (calderas) filled rapidly with late- stage volcanic rocks, landslide debris from the caldera walls and many types of sedimentary rocks that accumulated in the depression. Many calderas are the site of resurgent igneous bodies or domes and concentric dikes that occupy the collapse fault system. The complex igneous, tectonic, and sedimentary nature of collapse calderas makes them unpredictable as hydrogeologic features. Coarse landslide debris and some other caldera fill is permeable and the complicated network of faults and fractures may create fracture- flow. On the other hand, late stage intrusive rocks and alteration of the ubiquitous volcanic ash to form zeolite and clay minerals tends to decrease transmissivity so that collapse calderas can form barriers to aquifer systems. It is thus impossible to generalize about the effect of calderas on regional hydrology and each one must be evaluated on its own unique characteristics.

Tilt domains of Cenozoic strata (Sheet 15). Many fault-block ranges in the Basin and Range Province strike northerly and the rocks are tilted in a eastward or westward direction. This tilting is the result of late Cenozoic regional E-W crustal extension. The tilting is apparent by the inclination of Tertiary rocks. If two or more adjacent ranges (separated by bounding valleys) have the same tilt direction this region is classified as a tilt domain. The tilt domains used here were extrapolated from those outlined by Stewart and others, 1998. Basins between ranges in a domain are asymmetrical, the deepest part being adjacent to the faulted edge of the next range.

Both symmetry of the basin and the tilt of Cenozoic strata have effects on groundwater flow systems. The basin symmetry is a guide to the location of various basin-fill hydrogeologic units and the location of bounding faults. The tilt of the Cenozoic strata may control the direction of surface and shallow ground-water flow from range to basin.

Mapped Quaternary faults (Sheet 16). Quaternary faults cut alluvium and rock units locally creating flow paths for ground-water while in other places disrupting aquifers controlled by different permeability factors such as rock composition. The orientation, length, and density of young faults provide a guide to the location of aquifer systems and a quantitative measure of disruption of basin-filling sediments and basin-bounding rocks. The orientation of active fault systems, controlled by regional stress fields, strongly influences fracture flow of ground-water (Ingebritsen and Sanford, 1998). Maps showing 
the length and distribution of Quaternary faults in the DSW have been made by a number of researchers for different regions. Those used here include: Arizona (Pearthree, 1999); California (Jennings, 1994); Idaho (Nakata and others, 1982); Nevada (Dohrenwend and others,1996); New Mexico (Machette and others, 1998); Oregon (Nakata and others, 1982); and Utah (Black and others, 2003).

To calculate Quaternary fault density for the DSW, a grid with a cell size of $50 \mathrm{~km}^{2}$ was overlain on the map of Quaternary faults and the sum of the lengths of all faults in each cell, measured in kilometers, was divided by the area of the cell $\left(50 \mathrm{~km}^{2}\right)$ to produce fault density $\left(\mathrm{km} / \mathrm{km}^{2}\right)$. The fault densities for all the cells in the grid were contoured at $0.005 \mathrm{~km} / \mathrm{km}^{2}$ intervals and then superimposed on the fault map. The resulting contour map enables comparison of fault density with the other elements that effect ground-water such as those shown as areas on the different map sheets.

Paleotectonic maps of time intervals in the Cenozoic (Sheets 17-21). These five sheets are a series of paleotectonic maps that represent five different time periods during the Cenozoic: 55-38, 38-22, 22-17, 17-8, and 8-0 Ma. Each map portrays the geologic landscape of the DSW as it evolved during the last 55 million years. These interpretative maps represent periods during which a dominant geologic framework prevailed. Because tectonic systems are continuously evolving at different rates and at different places, the periods are of different lengths and adjacent periods grade into one another. The beginning and end of each period, defined at a certain age, is, in reality, a span of time measured in millions of years. Selection of different intervals or more intervals would give a somewhat different perspective of the geologic history of the region.

In most parts of the DSW the Cenozoic was a time of terrestrial erosion and sedimentation following the retreat of the Mesozoic seas. Various tectonic episodes in the Cenozoic produced various upland areas, and erosion of the uplands produced detritus that was deposited in generally easterly migrating lakes (Sheet 17). Broad erosional planes developed on the Mesozoic and older rocks and a regional unconformity between the Cenozoic and older rocks (generally referred to as basement) is a feature found throughout the DSW. During middle Cenozoic time, volcanism became significant in the northern and eastern Great Basin and the eastern part of the Mexican Highlands (see Index Map and Sheet 17). This volcanism, consisted mostly of ash-flows and lava flows of silicic, calc-alkaline petrochemistry, migrated southwestly across the Great Basin and was also occurring in the Mexican Highlands until about $22 \mathrm{Ma}$ (Sheet 18). These volcanic rocks were spread over large regions of low-to- moderate relief from regional erosion in early-to- middle Cenozoic time. No dominant tectonic system was characteristic of the DSW during this period. The inception of basin and range (graben and horst) faulting followed the cessation of calc-alkaline volcanism at $22 \mathrm{Ma}$ in the western part of the Sonoran Desert (Sheet 19). By about $17 \mathrm{Ma}$, basin and range faulting affected all parts of the Great Basin but started to wane in the southern parts of the Basin and Range Province (Sheets 20 and 21). Along the margin of the Great Basin and locally in the southern part of the Basin and Range Province, basaltic volcanism continued from 17 Ma until present.

\section{Hydrogeologic Framework as a Consequence of Geologic History (Table 1).}

Geologic history determines the stratigraphic and structural architecture that forms the hydrogeologic basis for understanding ground-water flow. Any studies of the hydrogeology of the DSW must take into consideration its tectonic and stratigraphic 
history. Geologic events that have occurred for nearly two billion years (since early Proterozoic time) have shaped the geologic framework of the DSW.

This table summarizes the sequential geologic events that have significantly affected the hydrogeologic framework in the different regions of the DSW. Geologic age decreases downward (non-linearly) along the vertical axis and major categories of geologic time are indicated by color bands. In order to emphasize the greater hydrogeologic significance of younger geologic events, the more recent parts of geologic time are expanded in this diagram. Blue shadings draw the reader's attention to events of greatest hydrogeologic significance for aquifers. Dark blue shading highlights geologic events that tended to form rocks and deposits that are now regional aquifers - events such as deposition of carbonate strata, or formation of deep structural basins that filled with permeable deposits. Events that formed local aquifers are indicated by light blue shading. Because much of the ground-water in the DSW resulted from recharge during the wetter climates of Pleistocene times, blue-green shading highlights the hydrogeologic significance of the Pleistocene.

\section{REFERENCES CITED}

Best, M.G., Christiansen, E.H., Deino, A.L., Gromme, C.S., McKee, E.H., and Noble, D.C., 1989, Eocene through Miocene volcanism in the Great Basin of the western United States, in Chapin, C.E. and Sidek, J., eds., Field excursions to volcanic terranes in the western United States, volume II ; Cascades and intermountain West: New Mexico Bureau of Mines and Mineral Resources, Memoir 47, p. 91-134.

Black, B.D., Hecker, S., Hylland, M.D., Christenson, G.E., and McDonald, G.N., 2003, Quaternary fault and fold database and map of Utah: Utah Geological Survey OpenFile Report 98-521, Scale 1:500000.

Dorhrenwend, J.C., Schell, B.A., Menges, C.M., Moring, B.C., and McKittrick, M.A., 1996, Reconnaissance photogeologic map of young (Quaternary and late Tertiary) faults in Nevada, in Singer, D.A., ed., An analysis of Nevada's metal-bearing mineral resources: Nevada Bureau of Mines and Geology Open-file Report 96-2, p, 9-1 to 9-12.

Fenneman, N.M. and Johnson, D.W., 1946, Physical divisions of the United States; U.S. Geological Survey Map, 1: 7,000,000

Jachens, R.C., Moring, B.C., and Schruben, P.G., 1996, Thickness of Cenozoic deposits and the isostatic gravity over basement, in Singer, D.A., ed., An analyais of Nevada's metal-bearing mineral resources: Nevada Bureau of Mines and Geology Open-file Report 96-2 p.2-1 to 2-10.

Jennings, C.W., 1994, Fault activity map of California and adjacent area, with locations and ages of recent volcanic eruptions: California Division of Mines and Geology Geologic Data Map no.6, Scale 1:750000.

Howard, K.A., Jachens, R.C., Chuang, F.C., McKee, E.H., and D’Agnese, F.A., 2003, Geohydrologic factors that influence the movement of ground water in the Great Basin: preliminary report: U.S. Geological Survey Open-File Report 03-XXX; 26 p.

Ingebritsen, S.E., and Sanford, W.E., 1998, mGroundwater in geologic processes: New York, Cambridge University Press, 341 p. 
Laczniak, R.J., Cole, J.C., Sawyer, D.A., and Trudeau, D.A., 1996, Summary of hydrogeologic controls on ground-water flow at the Nevada Test Site, Nye County,

Nevada: U.S. Geological Survey Water Resources Investigations Report 96-4109, 59 p.

Long, K.R., DeYoung, J.H., and Ludington, S.D., 1998, Significant deposits of gold, silver, copper, lead, and zinc in the United States: Economic Geology v. 95, p. 629644.

Machette, M.N., Personius, S.F., Kelson, K.I., Haller, K.M., and Dart, R.L., 1998, Map and database of Quaternary faults and folds in New Mexico: U.S. Geological Survey Open-File Report 98-521, Scale 1:750000.

McKee, E.H., 1996, Cenozoic magmatism and mineralization in Nevada in Geology and ore deposits of the American Cordillera, Symposium Proceedings, edited by Alan R. Coyner and Patrick L. Fahey: published by Geological Society of Nevada: p. 581-588.

McKee, E.H., 1997, Evaluation of geologic structure guiding ground-water flow south and west of Frenchman Flat, Nevada Test Site: U.S. Geological Survey Open-file Report 97-734.

Nakata, J.K., Wentworth, C.M., and Machette, M.N., 1982, Quaternary fault map of the Basin and Range and Rio Grande Rift province, western United States: U.S.

Geological Survey Open-File Report 82-579, Scale 1:2500000.

Pearthree, P.A., 1999, Quaternary fault data and map of Arizona: Arizona Geological Survey Open-File Report 98-24, Scale 1:750000.

Saltus, R.W.,1988, Bouguer gravity anomaly map of Nevada: Nevada Bureau of Mines and Geology Map 94A, scale 1: 750,000.

Saltus, R.W., and Jachens, R.C., 1995, Gravity and basin-depth maps of the Basin and Range Province, western United States: U.S. Geological Survey Geophysical Investigations Map GP-1012, scale 1: 2,500,000.

Stewart, J.H., and 19 additional co-authors, 1998, Map showing Cenozoic tilt domains and associated structural features, western North America (Plate 1): Geological Society of America Special Paper 323, Scale 1:5000000.

Winograd, I.T., and Thordarson, William, 1975, Hydrogeologic and hydrogeochemical framework, south-central Great Basin, Nevada-California, with special reference to the Nevada Test Site: U.S. Geological Survey Professional Paper 712-C, 126 p. 


\section{Description of data base for Open-File Report 03-294}

\section{Contents}

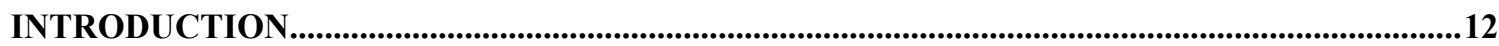

FOR THOSE WHO DON'T USE DIGITAL GEOLOGIC MAP DATABASES.............................. 12

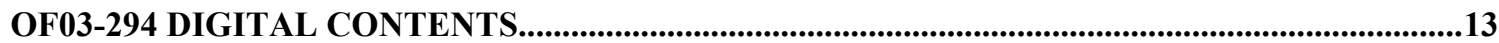

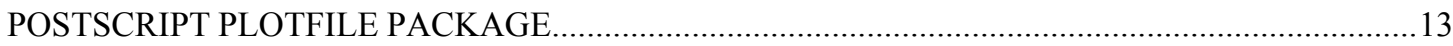

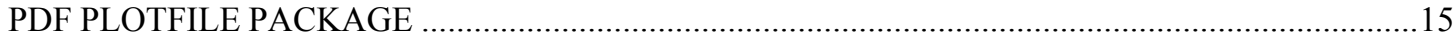

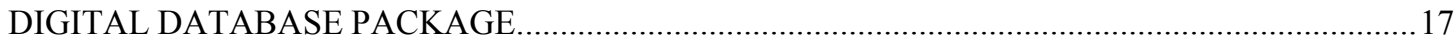

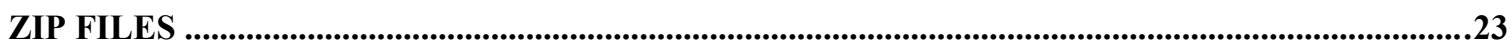

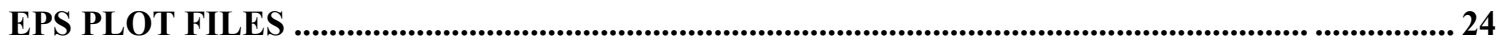

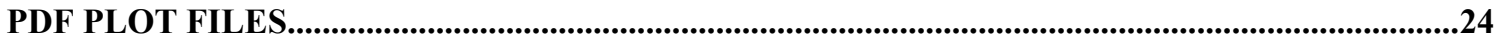

OBTAINING THE DIGITAL DATABASE AND PLOTFILE PACKAGES....................................... 25

TO OBTAIN THE PLOTFILE OR DIGITAL DATABASE PACKAGES FROM

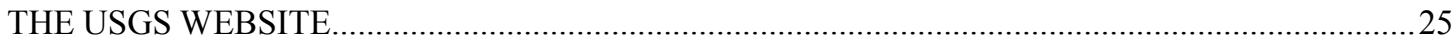

TO OBTAIN THE PLOTFILE OR DIGITAL DATABASE PACKAGES ON A

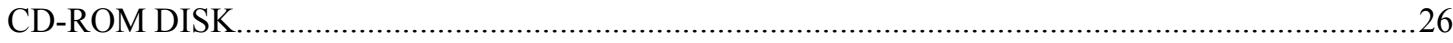

OBTAINING PLOTS FROM A COMMERCIAL VENDOR.............................................................. 26

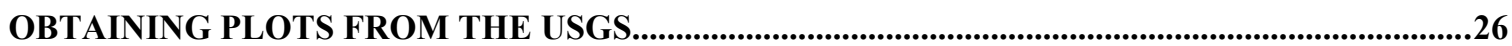

REVISIONS AND VERSION NUMBERS...........................................................................................26

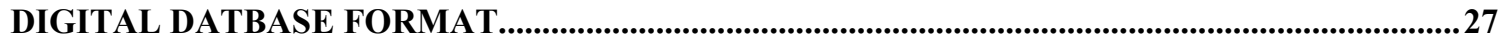

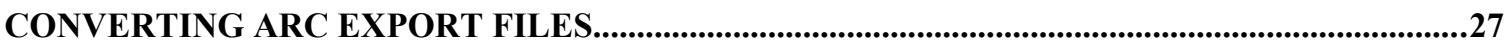

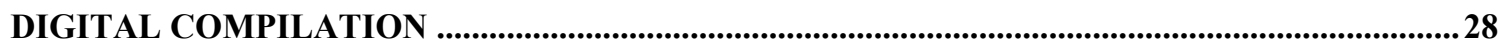

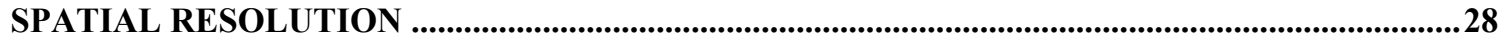

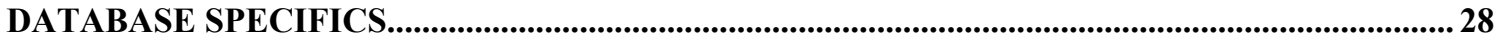

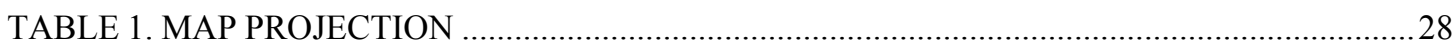

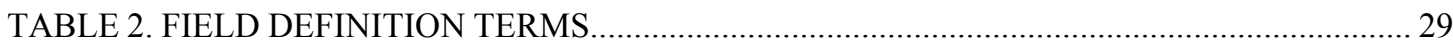

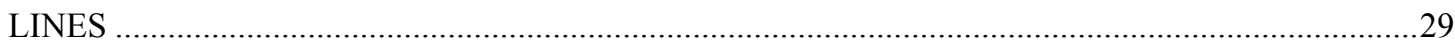

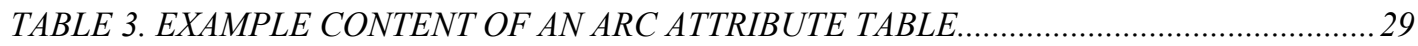

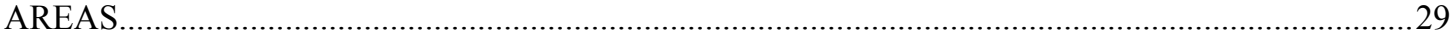

TABLE 4. EXAMPLE CONTENT OF A POLYGON ATTRIBUTE TABLE ...................................... 30

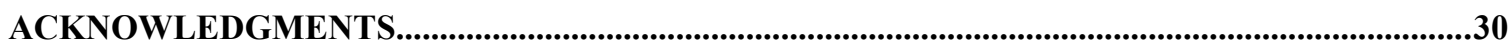

REFERENCES CITED _.............................................................................................................................. 30

REFERENCES CITED IN FGDC-COMPLIANT METADATA FILES..............................................30 
APPENDIX. GEOLOGIC UNITS FROM THE DIGITAL STATE GEOLOGIC MAPS USED TO

DEVLEOP HYDROGEOLOGIC UNITS.......................................................... 33 


\section{Introduction}

This pamphlet serves to introduce and describe the digital files that are included in this publication, available for downloading at http://geopubs.wr.usgs.gov. These data include both a set of Arc/Info geospatial databases containing geologic information and Adobe Acrobat PDF and PostScript plot files containing images of the geologic map sheets that includes text describing the geology of the area. For those solely interested in a paper plot of the maps, please see the section entitled "For Those Who Don't Use Digital Geologic Map Databases" below.

In this digital Open-File Report, we have taken geologic data from state geologic maps to develop a series of digital maps. These maps are used to evaluate the parameters (or elements) that might be expected to influence ground-water regimes in different parts of the desert southwest United States. A total of fifteen elements are identified and plotted on seperate maps that can be combined (computer or manually) to show which elements are present in different parts of the region. Some areas may contain all fifteen elements, other areas many contain any number of combinations of the elements. The elements present a first approximation of what should be the expected hydrogeologic setting of a sub-area within the desert southwest. In addition to the element maps, five paleo-tectonic maps at varying time intervals in the Cenozoic are presented. These paleotectonic maps indicate where and when different physiographic landscapes existed from $55 \mathrm{Ma}$ to present.

\section{For those who don't use digital geologic map databases}

For those interested in the digital geologic maps, but do not use an Arc/Info compatible Geographic Information System (GIS), we have provided two plotfile packages containing images of the database information. Each package contains a set of images of the 22 individual maps in this database. One package contains the images in Encapsulated PostScript format (EPS) and the other package contains images in Adobe Acrobat Portable Document format (PDF) (see sections "EPS plot files" and "PDF plot files" below).

Those interested who have computer capability can access the plot packages in one of two ways described below (see section "Obtaining the digital database and plotfile packages"). Please note that the plot file packages do require PC DOS/Windows zip utilities to access the plot files. Therefore additional software, available free on the Internet, may be required to use the plot files (see section "Zip files"). In addition, the map and explanation sheets are large, and require large-format color plotters to produce a plot of the entire image, although smaller plotters can be used to plot portions of the images using the PDF plot files (see sections "EPS plot files" and "PDF plot files" below).

Those without computer capability can obtain plots of the map files through USGS Map-On-Demand service for digital geologic maps (see section "Obtaining digital plots from USGS") or from an outside vendor (see section "Obtaining plots from an outside vendor). 
Also, USGS has adopted version numbers for publications, similar to that used in the computer industry. Therefore, this publication may be revised and upgraded from time to time. See the section "Revisions and version numbers" for details on this policy.

\section{OF03-294 digital contents}

This publication includes three digital packages. The first is the EPS Plotfile Package, which consists of Encapsulated PostScript plot files of all 22 maps in this publication. The second is the PDF Plotfile Package, and contains the same plotfiles as the first package, but in Portable Document Format. The third is the Digital Database Package, and contains the geologic database itself, a Microsoft Excel spreadsheet of Table 1 and Federal Geographic Data Committee (FGDC) compliant metadata.

\section{EPS plotfile package}

This package contains the images described here in Encapsulated PostScript format (see below for more information on PostScript plot files):

indexsheet.eps A EPS plottable file containing an image of the entire study area that includes all or parts of the states of Oregon, Idaho, California, Nevada, Utah, Arizona, New Mexico and Colorado.

sheet1.eps A EPS plottable file containing an image of the hydrogeologic map of the southwestern United States.

sheet2.eps A EPS plottable file containing an image of the unconsolidated alluvial deposits in the desert southwest United States.

sheet3.eps A EPS plottable file containing an image of the older coarsegrained subsurface basin fill deposits in the desert southwest United States.

sheet4.eps A EPS plottable file containing an image of the older finegrained subsurface basin fill deposits in the desert southwest United States.

sheet5.eps A EPS plottable file containing an image of the inferred distribution (surface and subsurface) of Cenozoic basaltic rocks.

sheet6.eps A EPS plottable file containing an image of the inferred distribution (surface and subsurface) of Cenozoic non-basaltic volcanic rocks.

sheet7.eps A EPS plottable file containing an image of the inferred distribution of crystalline rocks at depths of less than several 
kilometers.

sheet8.eps A EPS plottable file containing an image of the areas in which pre-Cenozoic coarse to fine-grained siliceous rocks of variable thickness in the surface and subsurface can be expected.

sheet9.eps A EPS plottable file containing an image of the areas in which pre-Cenozoic fine-grained siliceous rocks of variable thickness in the surface and subsurface can be expected.

sheet10.eps A EPS plottable file containing an image of the areas in which Cenozoic and older carbonate rocks of variable thickness in the surface and subsurface can be expected.

sheet11.eps A EPS plottable file containing an image of the areas with regional scale alteration related to mineral deposits in the desert southwest United States.

sheet12.eps A EPS plottable file containing an image of the deep basins containing alluvium and low density rocks in the desert southwest United States.

sheet13.eps A EPS plottable file containing an image of the symmetry of basins in the desert southwest United States.

sheet14.eps A EPS plottable file containing an image of the Cenozoic collapse calderas in the desert southwest United States.

sheet15.eps A EPS plottable file containing an image of the domains of regional tilt of Cenozoic strata in the desert southwest United States.

sheet16.eps A EPS plottable file containing an image of the density of Quaternary faults in the desert southwest United States.

sheet17.eps A EPS plottable file containing an image of the interpretative paleo-tectonic map of the southwest United States for the early part of Paleogene time, 38-55 Ma.

sheet18.eps A EPS plottable file containing an image of the interpretative paleo-tectonic map of the southwest United States for the latter part of Paleogene time, 22-38 Ma.

sheet19.eps A EPS plottable file containing an image of the interpretative paleo-tectonic map of the southwest United States for the early part of Neogene time, 17-22 Ma.

sheet20.eps A EPS plottable file containing an image of the interpretative 
paleo-tectonic map of the southwest United States for the latter part of Neogene time, 8-17 Ma.

sheet21.eps A EPS plottable file containing an image of the interpretative paleo-tectonic map of the southwest United States, 0-8 Ma.

\section{PDF plotfile package}

This package contains the images described here in PDF format (see below for more information on PDF plot files):

indexsheet.pdf A PDF plottable file containing an image of the entire study area that includes all or parts of the states of Oregon, Idaho, California, Nevada, Utah, Arizona, New Mexico and Colorado.

sheet1.pdf

A PDF plottable file containing an image of the hydrogeologic map of the southwestern United States.

sheet2.pdf

A PDF plottable file containing an image of the unconsolidated alluvial deposits in the desert southwest United States.

sheet3.pdf

A PDF plottable file containing an image of the older coarsegrained subsurface basin fill deposits in the desert southwest United States.

sheet4.pdf

A PDF plottable file containing an image of the older finegrained subsurface basin fill deposits in the desert southwest United States.

sheet5.pdf A PDF plottable file containing an image of the inferred distribution (surface and subsurface) of Cenozoic basaltic rocks.

sheet6.pdf

A PDF plottable file containing an image of the inferred distribution (surface and subsurface) of Cenozoic non-basaltic volcanic rocks.

sheet7.pdf A PDF plottable file containing an image of the inferred distribution of crystalline rocks at depths of less than several kilometers.

sheet8.pdf

A PDF plottable file containing an image of the areas in which pre-Cenozoic coarse to fine-grained siliceous rocks of variable thickness in the surface and subsurface can be expected.

sheet9.pdf

A PDF plottable file containing an image of the areas in which pre-Cenozoic fine-grained siliceous rocks of variable 
thickness in the surface and subsurface can be expected.

sheet10.pdf A PDF plottable file containing an image of the areas in which Cenozoic and older carbonate rocks of variable thickness in the surface and subsurface can be expected.

sheet11.pdf A PDF plottable file containing an image of the areas with regional scale alteration related to mineral deposits in the desert southwest United States.

sheet12.pdf A PDF plottable file containing an image of the deep basins containing alluvium and low density rocks in the desert southwest United States.

sheet13.pdf A PDF plottable file containing an image of the symmetry of basins in the desert southwest United States.

sheet14.pdf A PDF plottable file containing an image of the Cenozoic collapse calderas in the desert southwest United States.

sheet15.pdf A PDF plottable file containing an image of the domains of regional tilt of Cenozoic strata in the desert southwest United States.

sheet16.pdf A PDF plottable file containing an image of the density of Quaternary faults in the desert southwest United States.

sheet17.pdf A PDF plottable file containing an image of the interpretative paleo-tectonic map of the southwest United States for the early part of Paleogene time, 38-55 Ma.

sheet18.pdf A PDF plottable file containing an image of the interpretative paleo-tectonic map of the southwest United States for the latter part of Paleogene time, 22-38 Ma.

sheet19.pdf A PDF plottable file containing an image of the interpretative paleo-tectonic map of the southwest United States for the early part of Neogene time, 17-22 Ma.

sheet20.pdf A PDF plottable file containing an image of the interpretative paleo-tectonic map of the southwest United States for the latter part of Neogene time, 8-17 Ma.

sheet21.pdf A PDF plottable file containing an image of the interpretative paleo-tectonic map of the southwest United States, 0-8 Ma. 


\section{Digital database package}

This database package contains the geologic map database files for all 22 maps in this Open-File Report. The digital maps, or coverages, along with their associated INFO directory have been converted to uncompressed Arc/Info export files. Arc export files promote ease of data handling, and are usable by some Geographic Information Systems in addition to Arc/Info (see below for discussion of working with export files). Two of the digital maps contain Arc/Info shapefiles, which are not Arc/Info coverages, but behave similar to coverages. These files are stand-alone file types that can be exported from and imported into Arc/Info (see below for discussion of working with shapefiles). The Arc export files and the associated Arc/Info coverages, shapefiles and directories, as well as the additional digital material included in the database, are described below:

\begin{tabular}{|c|c|c|}
\hline $\begin{array}{l}\text { ARC/INFO } \\
\text { export file }\end{array}$ & $\begin{array}{l}\text { Resultant } \\
\text { coverage }\end{array}$ & Description of Coverage \\
\hline studyarea1.e00 & studyarea1/ & $\begin{array}{l}\text { The study area in the desert southwest United } \\
\text { States. This coverage includes arcs and } \\
\text { polygons. }\end{array}$ \\
\hline swlithologyc.e00 & swlithologyc/ & $\begin{array}{l}\text { The hydrogeologic units derived from the } \\
\text { geologic units of digital state geologic maps. } \\
\text { This coverage includes arcs and polygons. }\end{array}$ \\
\hline unconsol1c.e00 & unconsollc/ & $\begin{array}{l}\text { The unconsolidated alluvial deposits in the } \\
\text { desert southwest United States. This coverage } \\
\text { includes arcs and polygons. }\end{array}$ \\
\hline lowbfsdscgl1c.e00 & lowbfsdscgl1c/ & $\begin{array}{l}\text { The older coarse-grained subsurface basin } \\
\text { fill deposits in the desert southwest United } \\
\text { States. This coverage includes arcs and polygons }\end{array}$ \\
\hline lowbfmudss 1 c.e 00 & lowbfmudss $1 \mathrm{c} /$ & $\begin{array}{l}\text { The older fine-grained subsurface basin fill } \\
\text { deposits in the desert southwest United States. } \\
\text { This coverage includes arcs and polygons. }\end{array}$ \\
\hline qczbasalt1c.e00 & qczbasalt1c/ & $\begin{array}{l}\text { The inferred distribution (surface and } \\
\text { subsurface) of Cenozoic basaltic rocks in the } \\
\text { desert southwest United States. This coverage } \\
\text { includes arcs and polygons. }\end{array}$ \\
\hline otherczvolc1c.e00 & otherczvolc1c/ & $\begin{array}{l}\text { The inferred distribution (surface and } \\
\text { subsurface) of Cenozoic non-basaltic volcanic } \\
\text { rocks in the desert southwest United States. This } \\
\text { coverage includes arcs and polygons. }\end{array}$ \\
\hline
\end{tabular}




\begin{tabular}{|c|c|c|}
\hline preczcrystl1c.e00 & preczcrystl1c/ & $\begin{array}{l}\text { The inferred distribution of crystalline rocks at } \\
\text { depths of less than several kilometers. This } \\
\text { coverage includes arcs and polygons. }\end{array}$ \\
\hline preczsdscgl1c.e00 & preczsdscgl1c/ & $\begin{array}{l}\text { The areas in which pre-Cenozoic coarse to } \\
\text { fine-grained siliceous rocks of variable thickness } \\
\text { in the surface and subsurface can be expected. } \\
\text { This coverage includes arcs and polygons. }\end{array}$ \\
\hline preczchshss1c.e00 & preczchshss $1 \mathrm{c} /$ & $\begin{array}{l}\text { The areas in which pre-Cenozoic fine-grained } \\
\text { siliceous rocks of variable thickness in the } \\
\text { surface and subsurface can be expected. This } \\
\text { coverage includes arcs and polygons. }\end{array}$ \\
\hline preczcarb1c.e 00 & preczcarb1c/ & $\begin{array}{l}\text { The areas in which Cenozoic and older carbonate } \\
\text { rocks of variable thickness in the surface and } \\
\text { subsurface can be expected. This coverage } \\
\text { includes arcs and polygons. }\end{array}$ \\
\hline mindeposits.e 00 & mindeposits/ & $\begin{array}{l}\text { The areas with regional scale alteration related to } \\
\text { mineral deposits in the desert southwest United } \\
\text { States. This coverage includes arcs and } \\
\text { polygons }\end{array}$ \\
\hline calderasc.e00 & calderasc/ & $\begin{array}{l}\text { The Cenozoic collapse calderas in the desert } \\
\text { southwest United States. This coverage contains } \\
\text { arcs. }\end{array}$ \\
\hline basinaxes.e00 & basinaxes/ & $\begin{array}{l}\text { The asymmetry of basins in the desert southwest } \\
\text { United States. This coverage contains arcs. }\end{array}$ \\
\hline stewtiltc.e 00 & stewtiltc/ & $\begin{array}{l}\text { The domains of regional tilt direction of } \\
\text { Cenozoic strata in the desert southwest United } \\
\text { States. This coverage includes arcs and } \\
\text { polygons }\end{array}$ \\
\hline calk3855ma.e00 & calk3855ma/ & $\begin{array}{l}\text { The areas of calc-alkaline volcanic rocks in the } \\
\text { southwest United States for the early part of } \\
\text { Paleogene time, } 38-55 \text { Ma. This coverage } \\
\text { includes arcs and polygons. }\end{array}$ \\
\hline calk2238ma.e00 & calk2238ma/ & $\begin{array}{l}\text { The areas of calc-alkaline volcanic rocks in the } \\
\text { southwest United States for the latter part of } \\
\text { Paleogene time, 22-38 Ma. This coverage } \\
\text { includes arcs and polygons. }\end{array}$ \\
\hline calk1722ma.e00 & calk1722ma/ & The areas of calc-alkaline volcanic rocks in the \\
\hline
\end{tabular}


southwest United States for the early part of Neogene time, 17-22 Ma. This coverage includes arcs and polygons.

\begin{tabular}{|c|c|c|}
\hline calk17ssmalw.e00 & calk17ssmalw/ & $\begin{array}{l}\text { The areas of fault-bounded basins in the } \\
\text { southwest United States for the early part of } \\
\text { Neogene time, } 17-22 \text { Ma. This coverage includes } \\
\text { arcs and polygons. }\end{array}$ \\
\hline basalt817ma.e00 & basalt $817 \mathrm{ma} /$ & $\begin{array}{l}\text { The areas of basaltic rocks and the Cascade } \\
\text { volcanic arc in the southwest United States for } \\
\text { the latter part of Neogene time, } 8-17 \text { Ma. This } \\
\text { coverage includes arcs and polygons. }\end{array}$ \\
\hline basalt817malw.e00 & basalt817malw/ & $\begin{array}{l}\text { The area of fault-bounded basins and the Rio } \\
\text { Grande Rift in the southwest United States for } \\
\text { the latter part of Neogene time, } 8-17 \mathrm{Ma} \text {. This } \\
\text { coverage includes arcs and polygons. }\end{array}$ \\
\hline basalt08ma.e00 & basalt08ma/ & $\begin{array}{l}\text { The areas of basaltic rocks and the Cascade } \\
\text { volcanic arc in the southwest United States, } \\
0-8 \mathrm{Ma} \text {. This coverage includes arcs and } \\
\text { polygons. }\end{array}$ \\
\hline basalt08malw.e 00 & basalt08malw/ & $\begin{array}{l}\text { The areas of fault-bounded basins, aggraded } \\
\text { plains, alluvial basins and the Rio Grande Rift } \\
\text { in the southwest United States, } 0-8 \mathrm{Ma} \text {. This } \\
\text { coverage includes arcs and polygons. }\end{array}$ \\
\hline $\begin{array}{l}\text { ARC/INFO } \\
\text { shapefile }\end{array}$ & $\begin{array}{l}\text { Associated } \\
\text { Arc/Info files }\end{array}$ & Description of Coverage \\
\hline basincont $1 \mathrm{k} . \mathrm{sh} p$ & $\begin{array}{l}\text { basincont } 1 \mathrm{k} . \mathrm{shx} \\
\text { basincont } 1 \mathrm{k} . \mathrm{sbn} \\
\text { basincont } 1 \mathrm{k} . \mathrm{sbx} \\
\text { basincont } 1 \mathrm{k} . \mathrm{dbf} \\
\text { basincont } 1 \mathrm{k} . \mathrm{prj}\end{array}$ & $\begin{array}{l}\text { The contour lines of basin depth at } 1 \\
\text { kilometer intervals for the desert southwest } \\
\text { United States. This file has other associated } \\
\text { Arc/Info files necessary to convert from a } \\
\text { shapefile to an Arc coverage. }\end{array}$ \\
\hline nmcont $1 \mathrm{k} . \mathrm{shp}$ & $\begin{array}{l}\text { nmcont } 1 \mathrm{k} \cdot \mathrm{shx} \\
\mathrm{nmcont} 1 \mathrm{k} \cdot \mathrm{sbn} \\
\mathrm{nmcont} 1 \mathrm{k} \cdot \mathrm{sbx} \\
\text { nmcont } 1 \mathrm{k} \cdot \mathrm{dbf} \\
\text { nmcont } 1 \mathrm{k} \cdot \mathrm{prj}\end{array}$ & $\begin{array}{l}\text { The contour lines of basin depth at } 1 \\
\text { kilometer intervals for New Mexico. This } \\
\text { file has other associated Arc/Info files } \\
\text { necessary to convert from a shapefile to an } \\
\text { Arc coverage. }\end{array}$ \\
\hline qfdensity005.shp & $\begin{array}{l}\text { qfdensity005.shx } \\
\text { qfdensity005.sbn } \\
\text { qfdensity005.sbx } \\
\text { qfdensity005.dbf }\end{array}$ & $\begin{array}{l}\text { The contour lines of Quaternary fault } \\
\text { density at } 0.005 \mathrm{~km} / \mathrm{km} 2 \text { intervals for the } \\
\text { desert southwest United States. This file has } \\
\text { other associated Arc/Info files necessary to }\end{array}$ \\
\hline
\end{tabular}


qfdensity005.prj convert from a shapefile to an Arc coverage.

The database also includes the following Arc coverages and files:

\begin{tabular}{|c|c|c|}
\hline $\begin{array}{l}\text { ARC/INFO } \\
\text { export file }\end{array}$ & $\begin{array}{l}\text { Resultant } \\
\text { coverage }\end{array}$ & Description of Coverage \\
\hline latlonlines.e00 & latlonlines/ & $\begin{array}{l}\text { Latitude and longitude lines at } 4 \text { degree intervals } \\
\text { for all } 22 \text { digital maps. This coverage contains } \\
\text { lines. }\end{array}$ \\
\hline latlontics.e00 & latlontics/ & $\begin{array}{l}\text { Cross-hair tic marks between latitude and } \\
\text { longitude lines for all } 22 \text { digital maps. This } \\
\text { coverage contains lines. }\end{array}$ \\
\hline states_alb.e 00 & states_alb/ & $\begin{array}{l}\text { State boundaries for all } 50 \text { states and includes } \\
\text { the U.S. Virgin Islands. This coverage includes } \\
\text { lines and polygons. }\end{array}$ \\
\hline
\end{tabular}

PDF files, ASCII text files, Microsoft Excel spreadsheet file, and ASCII text files of Federal Geographic Data Committee (FGDC) compliant metadata files:

of03-294.pdf

readme.txt

table1.xls

studyarea1.met

swlithologyc.met

unconsollc.met

lowbfsdscgl1c.met
A PDF file of a pamphlet describing the digital and scientific results of this publication, OF03-294 (this pamphlet).

ASCII text file of a pamphlet describing the digital database contents of this publication.

A Microsoft Excel spreadsheet file of Table 1 in this publication, OF03-294.

A text-only file of publication level FGDC compliant metadata for the study area in the desert southwest United States.

A text-only file of publication level FGDC compliant metadata for the hydrogeologic units derived from the geologic units of digital state geologic maps.

A text-only file of publication level FGDC compliant metadata for the unconsolidated alluvial deposits in the desert southwest United States.

A text-only file of publication level FGDC compliant 
metadata for the older coarse-grained subsurface basin fill deposits in the desert southwest United States.

lowbfmudss1c.met A text-only file of publication level FGDC compliant metadata for the older fine-grained subsurface basin fill deposits in the desert southwest United States

qczbasalt1c.met

A text-only file of publication level FGDC compliant metadata for the inferred distribution (surface and subsurface) of Cenozoic basaltic rocks in the desert southwest United States.

otherczvolc1c.met A text-only file of publication level FGDC compliant metadata for the inferred distribution (surface and subsurface) of Cenozoic non-basaltic volcanic rocks in the desert southwest United States.

preczcrystl1c.met

A text-only file of publication level FGDC compliant metadata for the inferred distribution of crystalline rocks at depths of less than several kilometers.

preczsdscgl1c.met A text-only file of publication level FGDC compliant metadata for the areas in which pre-Cenozoic coarse to finegrained siliceous rocks of variable thickness in the surface and subsurface can be expected.

preczchshss1c.met A text-only file of publication level FGDC compliant metadata for the areas in which pre-Cenozoic fine-grained siliceous rocks of variable thickness in the surface and subsurface can be expected.

preczcarb1c.met A text-only file of publication level FGDC compliant metadata for the areas in which Cenozoic and older carbonate rocks of variable thickness in the surface and subsurface can be expected.

mindeposits.met A text-only file of publication level FGDC compliant metadata for the areas with regional scale alteration related to mineral deposits in the desert southwest United States.

calderasc.met A text-only file of publication level FGDC compliant metadata for the Cenozoic collapse calderas in the desert southwest United States.

basinaxes.met A text-only file of publication level FGDC compliant metadata for the symmetry of basins in the desert southwest United States. 
stewtiltc.met

calk3855ma.met

calk2238ma.met

calk1722ma.met

calk17ssmalw.met

basalt817ma.met

basalt817malw.met

basalt08ma.met

basalt08malw.met

basincont1k.met

nmcont1k.met
A text-only file of publication level FGDC compliant metadata for the domains of regional tilt of Cenozoic strata in the desert southwest United States.

A text-only file of publication level FGDC compliant metadata for the areas of calc-alkaline volcanic rocks in the southwest United States for the early part of Paleogene time, 38-55 Ma.

A text-only file of publication level FGDC compliant metadata for the areas of calc-alkaline volcanic rocks in the southwest United States for the latter part of Paleogene time, 22-38 Ma.

A text-only file of publication level FGDC compliant metadata for the areas of calc-alkaline volcanic rocks in the southwest United States for the early part of Neogene time, 17-22 Ma.

A text-only file of publication level FGDC compliant metadata for the areas of fault-bounded basins in the southwest United States for the early part of Neogene time, 17-22 Ma.

A text-only file of publication level FGDC compliant metadata for the areas of basaltic rocks and the Cascade volcanic arc in the southwest United States for the latter part of Neogene time, 8-17 Ma.

A text-only file of publication level FGDC compliant metadata for the area of fault-bounded basins and the Rio Grande Rift in the southwest United States for the latter part of Neogene time, 8-17 Ma.

A text-only file of publication level FGDC compliant metadata for the areas of basaltic rocks and the Cascade volcanic arc in the southwest United States, 0-8 Ma.

A text-only file of publication level FGDC compliant metadata for the areas of fault-bounded basins, aggraded plains, alluvial basins and the Rio Grande Rift in the southwest United States, 0-8 Ma.

A text-only file of publication level FGDC compliant metadata for the contour lines of basin depth at 1 kilometer intervals for the desert southwest United States.

A text-only file of publication level FGDC compliant 
metadata for the contour lines of basin depth at 1 kilometer intervals for New Mexico.

qfdensity005.met A text-only file of publication level FGDC compliant metadata for the contour lines of Quaternary fault density at $0.005 \mathrm{~km} / \mathrm{km} 2$ intervals for the desert southwest United States.

The following supporting directory is not included in the database package, but is produced in the process of reconverting the export files into Arc coverages:

info/ INFO directory containing files supporting the databases.

\section{Zip files}

The three data packages described above are stored in zip (DOS/Windows compression format) files. A zip utility is required to extract the data from the zip file. This utility is included in most PC systems, and can be obtained for a variety of platforms free of charge over the Internet from Internet Literacy's Common Internet File Formats Webpage:

http://www.matisse.net/files/formats.html

The zip file itself is slightly compressed and when the archived files are extracted the zip file is automatically uncompressed. Winzip for PC Windows and Zip It for Macintosh computers, are both decompression utilities available free of charge at the following websites:

(http://www.awa.com/softlock/zipit/zipit.html) - Zip It file decompression for Macintosh (ftp://ftp.cdrom.com/pub/cica/win3/util/) - WinZip file decompression for PC Windows

When the zip file is uncompressed and the data from the zip file is extracted, the files can be put in a directory of the user's choice. The specifics of the zip files are listed below:

\begin{tabular}{lll}
$\begin{array}{l}\text { Name of } \\
\text { compressed } \\
\text { zip file }\end{array}$ & $\begin{array}{l}\text { Size of } \\
\text { compressed } \\
\text { zip file } \\
\text { (uncompressed) }\end{array}$ & $\begin{array}{l}\text { Data package } \\
\text { contained }\end{array}$ \\
\hline----- & -------- \\
of03-294ps.zip & $20 \mathrm{MB}(260 \mathrm{MB})$ & EPS plotfile package \\
of03-294pdf.zip & $12 \mathrm{MB}(13 \mathrm{MB})$ & PDF plotfile package \\
of03-294db.zip & $27 \mathrm{MB}(108 \mathrm{MB})$ & Digital database package
\end{tabular}




\section{EPS plot files}

For those interested in the geologic data for this publication, but don't use an Arc/Info compatible GIS system we have included a separate data package with 22 PostScript plot files. Of the 22 files, the first 15 files after the index file (index.eps) and the sheet 1 file (sheet1.eps) are related to the 15 element maps described earlier in this pamphlet (see Introduction section above). These 15 map files can be divided into five groups related to geologic parameters. [1] unconsolidated younger sediments and sedimentary rocks, mostly of Cenozoic age (Sheet 2, Sheet 3, Sheet 4, sheet2.eps, sheet3.eps, sheet4.eps); [2] lithified material including basaltic rocks of Cenozoic age (Sheet 5, sheet5.eps), other types of volcanic rocks of Cenozoic age (Sheet 6, sheet6.eps), crystalline rocks including granitoids, gneisses and schists of any age but mostly older than Cenozoic (Sheet 7, sheet7.eps), siliceous and carbonate rocks mostly of preCenozoic age (Sheet 8, Sheet 9, Sheet 10, sheet8.eps, sheet9.eps, sheet10.eps); [3] regional alteration (Sheet 11, sheet11.eps); [4] basins with a variety of unlithified and lithified fill (Sheet 12, Sheet 13, sheet12.eps, sheet13.eps); [5] tectonic-structural features (Sheet 14, Sheet 15, Sheet 16, sheet14.eps, sheet15.eps, sheet16.eps).

The last five map files are related to the paleo-tectonic maps as described earlier in this pamphlet (see Introduction section above). These 6 map files correspond to Sheets 17-21 in this publication (sheet17.eps, sheet18.eps, sheet19.eps, sheet20.eps, sheet21.eps). These interpretative maps show the most recent geologic history of the southwestern U.S. at varying time intervals in the Cenozoic.

The PostScript image for all 22 digital maps (index.eps, sheet1.eps to sheet21.eps) are at 1:2,000,000 scale and set for 34 inches wide by 44 inches high plot size, so it requires a large plotter to produce paper copies at the intended scale. Therefore, the paper must be at least 36 inches wide to correctly output these hardcopy maps.

The PostScript plotfiles were produced in ArcMap (part of ArcGIS, Arc/Info version 8.2) by printing the finished maps to a Encapsulated PostScript file.

\section{PDF plot files}

A second plot package contains PDF versions of the 22 EPS map sheets. Adobe Acrobat PDF (Portable Document Format) files are similar to EPS plot files in that they contain all the information needed to produce a paper copy of a map or pamphlet and they are platform independent. Their principle advantage is that they require less memory to store and are therefore quicker to download from the Internet. In addition, PDF files allow for relatively easy printing of portions of a map image on a printer smaller than that required to print the entire map without the purchase of expensive additional software. All PDF files in this report have been created from EPS plot files using Adobe Acrobat Distiller. In test plots we have found that paper maps created with PDF files contain almost all the detail of the maps created with PostScript plot files. We would, however, recommend that those users with the capability to print the large PostScript plot files to do so in preference to the PDF files.

To use the PDF files, the user must download and install a copy of Adobe Acrobat Reader. This software is available free of charge from the Adobe website (http://www.adobe.com). Please follow the instructions given at the website for 
installation. Once installed, the Acrobat Reader software contains an on-line manual and tutorial.

There are two ways to use Acrobat Reader in conjunction with the Internet. One is to use the PDF reader plug-in with your Internet browser. This allows for interactive viewing of PDF file images within your browser. This is a very handy way to quickly look at PDF files without downloading them to your hard disk. The second way is to download the PDF file to your local hard disk, and then view the file with Acrobat Reader. We strongly recommend that large map images be handled by downloading to your hard disk, because viewing them within an Internet browser tends to be very slow.

To print a smaller portion of a PDF map image using Acrobat Reader, it is necessary to cut out the portion desired using Acrobat Reader and the standard cut and paste tools for your platform, and then to paste the portion of the image into a file generated by another software program that can handle images. Most word processors (such as Microsoft Word) will suffice. The new file can then be printed. Image conversion in the cut and paste process, as well as changes in the scale of the map image, may result in loss of image quality. Test plots of a converted image, however, have proven adequate in most cases. Software designed to handle images (Photoshop, Illustrator) do a better job.

\section{Obtaining the Digital Database and Plotfile Packages}

The digital data can be obtained in either of two ways:

1. From the USGS Western Region Publications Group Webpage

2. Request for a CD-ROM disk (limited quantities available)

\section{To obtain the Plotfile or Digital Database packages from the USGS website:}

The U.S. Geological Survey supports a set of graphical pages on the World Wide Web. Digital publications (including this one) can be accessed via these pages. The location of the main Web page for the entire USGS is

http://www.usgs.gov

The web server for digital publications from the Western Region is

http://geopubs.wr.usgs.gov

or goto

http://geopubs.wr.usgs.gov/open-file/of03-294

to access this publication. Besides providing easy access to the entire digital database, this Web page also affords easy access to the PostScript and PDF plot files for those who do not use digital databases (see below). 


\section{To obtain the Plotfile or Digital Database packages on a CD-ROM disk:}

The two Plotfile packages and Digital Database package can be obtained by sending a request (postal or electronic mail) with return address to:

Geologic Database of the Desert southwest United States

U.S. Geological Survey

345 Middlefield Road, MS 975

Menlo Park, CA 94025

Attn: Edwin H. McKee

Do not omit any part of this address! Please send e-mail requests to: mckee@usgs.gov

NOTE: Individual files cannot be sent on CD-ROM. Please access these files via the USGS website listed above.

\section{Obtaining plots from a commercial vendor}

Those interested in the geologic data of the desert southwest United States, but do not use a computer or the Internet, can still obtain the information. We will provide the PostScript or PDF plot files on a CD-ROM disk for use by commercial vendors who can make large-format plots. Make sure your vendor is capable of reading CD-ROM disks and PostScript or PDF files.

\section{Obtaining plots from the USGS}

The U.S. Geological Survey provides a map-on-demand service for certain plot files, such as those described in this document. To obtain plots of the geologic data in the desert southwest United States and any supporting documents (this pamphlet), contact:

USGS Information Services

Box 25286

Denver Federal Center

Denver, CO 80225-0046

Phone: (303) 202-4200

Fax: (303) 202-4695

E-Mail: infoservices@usgs.gov

\section{Revisions and version numbers}

From time to time, new information and mapping, or other improvements, will be integrated into this publication. Rather than releasing an entirely new publication, the 
USGS has adopted a policy of using version numbers similar to that used in the computer industry. The original version of all publications will be labeled Version 1.0. Subsequent small revisions will be denoted by the increase of the numeral after the decimal, while large changes will be denoted by increasing the numeral before the decimal. Pamphlets and map products will be clearly marked with the appropriate version number. Information about the changes, if any, that have been made since the release of Version 1.0 will be listed in the publication revision file. This file will be available at the publication web site (see above), and will also be included in the digital database package. A simplified version of the revision list will be included in the publication metadata.

\section{Digital database format}

The databases in this publication were compiled in Arc/Info, a commercial Geographic Information System produced by Environmental Systems Research Institute, Redlands, California (ESRI), with version 3.1 of the menu interface ALACARTE (Fitzgibbon and Wentworth, 1991; Fitzgibbon, 1991; Wentworth and Fitzgibbon, 1991) and ArcGIS Version 8.2 for the PC Windows operating system. The files are in COVERAGE (Arc/Info vector data) format or Shapefile (Arc/Info vector data) format. Coverages are stored in uncompressed Arc export format (Arc/Info version 7.x). Arc export files (.e00 extension) can be converted into Arc coverages in Arc/Info (see below) and can be read by some other Geographic Information Systems, such as MapInfo via ArcLink and ESRI's ArcView (free limited version for PC Windows from ESRI's website: http://www.esri.com). Arc shapefiles (.shp extension) come with 5 other files with the same filename, but diferent extensions (.shx, .sbn, .sbx, .dbf, .prj). The principle shapefile (with .shp extension) can be used much like a coverage in Arc/Info, but one must remember the file is not a coverage nor is it part of any coverage. These files do not contain any topological information such as that found in Arc coverages. Shapefiles, however, can be converted into a coverage in ArcGIS, using the ArcToolBox interface.

The digital compilation was done in two operating system environments. In the UNIX environment, Arc/Info version 7.2.1 with version 3.1 of the menu interface ALACARTE (Fitzgibbon and Wentworth, 1991; Fitzgibbon, 1991; Wentworth and Fitzgibbon, 1991) was used. In the PC Windows environment, ArcGIS version 8.2 along with the full workstation suite of tools such as GRID, TIN, etc was used.

\section{Converting Arc export files}

Arc export files are converted to Arc coverages using the Arc command IMPORT with the option COVER. Arc export files can also be read by some other Geographic Information Systems. Please consult your GIS documentation to see if you can use Arc export files and the proceedure to import them. 


\section{Digital compilation}

The geologic data was collected and developed from a variety of sources: digital GIS datasets available at USGS or other spatial database-related websites, digital files acquired from scientists within the USGS, and digitizing of mapped features on mylar or paper maps. Details of the original digital GIS datasets or other digital files can be found in the various FGDC compliant metadata included in the Digital Database package. The digitized maps were done on a CalComp digitizing table and then transformed from digitizing cooridnates to projection coordinates with digital tics placed by hand at known locations on the earth, such as the intersection of latitude and longitude coordinates.

\section{Spatial resolution}

Use of this digital geologic data should not violate the spatial resolution of the data. Although the digital form of the data removes the constraint imposed by the scale of a paper map, the detail and accuracy inherent in map scale are also present in the digital data. This dataset was edited at a scale of 1:2,000,000 and although higher resolution information was used in the interpretation of some of the maps, the intended use for these maps is at the 1:2,000,000 regional scale. Plotting at scale larger than 1:2,000,000 will not yield greater detail, although it may reveal fine-scale irregularities below the intended resolution of the database. Similarly, where this database is used in combination with other data of higher resolution, the resolution of the combined output will be limited by the lowest resolution of these data.

\section{Database specifics}

What follows is a brief and simple description of the databases included in this report and the data in them. For a comprehensive look at the database structure and content, please see the FGDC metadata files (.met extension), included in the database package and available separately at the publication web page.

The map databases consist of Arc coverages, shapefiles and supporting INFO files, which are stored in a Albers (Albers Conical Equal Area) projection (Table 1).

Table 1. Map Projection

PROJECTION ALBERS

UNITS METERS

DATUM NAD27 (North American Horizontal Datum of 1927)

SPHEROID CLARKE1866 (Arc/Info default)

PARAMETERS

$1^{\text {st }}$ standard parallel 293000

$2^{\text {nd }}$ standard parallel 453000

central meridian -9600

latitude of projection's origin 2300 
false easting (meters) 0

flase northing (meters) 0

The content of the geologic database can be described in terms of the lines and areas that compose the map. Descriptions of the database fields use the terms explained in Table 2.

Table 2. Field Definition Terms

ITEM NAME name of the database field (item)

WIDTH maximum number of digits or characters stored

OUTPUT output width

TYPE B-binary integer, F-binary floating point integer, I-ASCII integer, C-ASCII character string, N-number with decimal places

N. DEC. number of decimal places maintained for floating point numbers

\section{Lines}

The lines (arcs) are recorded as strings of vectors and are described in the arc attribute table (an example of the format of arc attribute tables is shown in Table 3). They define the boundaries of the mapped features and the map boundaries. The first seven items in the "item name" column of any line coverage in Arc/Info are defined by the GIS software. Any items after the first seven are usually user-defined attribute items for particular lines or all lines in the coverage. These items are typically explained in the FGDC metadata files associated with each coverage and will not be described here.

Table 3. Example content of an Arc Attribute Table

\section{ITEM NAME WIDTH OUTPUT TYPE N. DEC}

\begin{tabular}{|c|c|c|c|c|c|}
\hline FNODE\# & 4 & 5 & $\mathrm{~B}$ & & arc starting node (from node) \\
\hline TNODE\# & 4 & 5 & $\mathrm{~B}$ & & arc ending node (to node) \\
\hline LPOLY\# & 4 & 5 & $\mathrm{~B}$ & & polygon to the left of the arc \\
\hline RPOLY\# & 4 & 5 & $\mathrm{~B}$ & & polygon to the right of the arc \\
\hline LENGTH & 4 & 12 & $\mathrm{~F}$ & 3 & length of arc in meters \\
\hline$<$ coverage $>\#$ & 4 & 5 & $\mathrm{~B}$ & & unique internal control number \\
\hline$<$ coverage $>$-ID & 4 & 5 & B & & unique identification number \\
\hline
\end{tabular}

\section{Areas}

The areas (polygons) are regions enclosed by lines and are described in the polygon attribute table (an example of the format of polygon attribute tables is shown in Table 4). Arc/Info coverages cannot contain both point and polygon information, so only coverages with polygon information will have a polygon attribute table, and these coverages will not have a point attribute table. The first four items in the "item name" column of any polygon coverage in Arc/Info are defined by the GIS software. Any items 
after the first four are usually user-defined attribute items for particular polygons or all polygons in the coverage. These items are typically explained in the FGDC metadata files associated with each coverage and will not be described here.

Table 4. Example content of a Polygon Attribute Table

ITEM NAME WIDTH OUTPUT TYPE N. DEC

$\begin{array}{llllll}\text { AREA } & 4 & 12 & \text { F } & 3 & \text { area of polygon in sq. meters } \\ \text { PERIMETER } & 4 & 12 & \text { F } & 3 & \text { length of perimeter in meters } \\ \text { <coverage }>\# & 4 & 5 & \text { B } & & \text { unique internal control number } \\ \text { <coverage>-ID } & 4 & 5 & \text { B } & & \text { unique identification number }\end{array}$

\section{Acknowledgments}

The authors are grateful to the following USGS scientists (current and emeritus) for their input in developing the maps and scientific content for this publication: R.C. Jachens, D. Sweetkind, F.A. D’Agnese, J.M. Harrill, J.R. Bartolino. In particular, the authors are grateful to R.C. Jachens for providing the raster data of gravity-derived depth to Cenozoic basement in the southwest United States. This dataset was instrumental in terms of understanding basin geometry and shape that are portrayed in the maps of this publication.

The first author would like to acknowledge A.D. Konieczki and J.A. Rees of the USGS Water Resources Division in Tucson, AZ for their help in gathering and providing digital datasets in the early stages of this publication. Thanks also to D. Bedford (USGS) for providing the digital state geologic map units of California, Nevada, and Utah and to V.E. Langenheim (USGS) for providing the digital Quaternary fault datasets used to make map sheet 16 .

The first author would also like to thank M. Diggles, R. Graymer and D. Bedford of USGS-Menlo Park, CA for their advice on metadata development and presentation.

\section{References Cited}

Fitzgibbon, T.T., 1991, ALACARTE installation and system manual (version 1.0): U.S. Geological Survey Open-File Report 91-587-B.

Fitzgibbon, T.T., and Wentworth, C.M., 1991, ALACARTE user-interface - AML code and demonstration maps (version 1.0): U.S. Geological Survey Open-File Report 91587-A.

Wentworth, C.M., and Fitzgibbon, T.T., 1991, ALACARTE user manual (version 1.0): U.S. Geological Survey Open-File Report 91-587-C.

\section{References Cited in FGDC-compliant Metadata files}


Anderson, O.J., and Jones, G.E., 1997, The digital geologic map of New Mexico: New Mexico Bureau of Mines and Geology Open-File Report 97-52, Scale 1:500000.

Black, B.D., Hecker, S., Hylland, M.D., Christenson, G.E., and McDonald, G.N., 2003, Quaternary fault and fold database and map of Utah: Utah Geological Survey OpenFile Report 98-521, Scale 1:500000.

Dohrenwend, J.C., Schell, B.A., Menges, C.M., Moring, B.C., and McKittrick, M.A., 1996, Reconnaisance photogeologic map of young (Quaternary and late-Tertiary) faults in Nevada: Nevada Bureau of Mines and Geology Open-File Report 96-2, p. 9-1 to $9-12$.

Fenneman, N.M., 1931, Physiography of western United States: McGraw-Hill, New York, $534 \mathrm{pp}$.

Fenneman, N.M., 1946, Physical divisions of the United States: U.S. Geological Survey, Scale 1:7000000.

Green, G.N., 1992, The digital geologic map of Colorado: U.S. Geological Survey OpenFile Report 92-507, Scale 1:500000.

Grubensky, M.J., and Bagby, W.C., 1990, Miocene calc-alkaline magmatism, calderas, and crustal extension in the Kofa and Castle Dome mountains, southwestern Arizona: Journal of Geophysical Research, v. 95, p. 19989-20003.

Hintze, L.F., Willis, G.C., Laes, D.Y.M., Sprinkel, D.A., and Brown, K.D., 2000, Digital geologic map of Utah: Utah Geological Survey, 179DM (CD-ROM), Scale 1:500000.

Hirschberg, D.M., and Pitts, G.S., 2000, Digital Geologic Map of Arizona: A Digital Database derived from the 1983 printing of the Wilson, Moore, and Cooper 1:500,000scale map: Arizona Geological Survey Open-File Report 00-409, Scale 1:500000.

Jachens, R.C., and Moring, B.C., 1996, Thickness of Cenozoic deposits and the isostatic residual gravity over basement: Nevada Bureau of Mines and Geology Open-File Report 96-2, p. 2-1 to 2-10.

Jennings, C.W., 1994, Fault activity map of California and adjacent area, with locations and ages of recent volcanic eruptions: California Division of Mines and Geology Geologic Data Map no.6, Scale 1:750000.

Johnson, B.R., and Raines G.L., 1995, Digital representation of the Idaho state geologic map: A contribution to the Interior Columbia River Basin Ecosystem Management Project: U.S. Geological Survey Open-File Report 95-690, Scale 1:500000.

Long, K.R., DeYoung, J.H., and Ludington, S.D., 1998, Significant deposits of gold, silver, copper, lead, and zinc in the United States: U.S. Geological Survey Open-File Report 98-206B (diskette).

Ludington, S., Cox, D.P., Leonard, K.W., and Moring, B.C., 1996, Ceozoic volcanic geology of Nevada: Nevada Bureau of Mines and Geology Open-File Report 96-2, p. 5-1 to 5-10.

Luedke, R.G., 1993, Map showing distribution, composition, and age of early and middle Cenozoic volcanic centers in Arizona, New Mexico, and west Texas: U.S. Geological Survey Misc-Invest. Map 2291-A, Scale 1:1000000.

Luedke, R.G., 1993, Map showing distribution, composition, and age of early and middle Cenozoic volcanic centers in Colorado and Utah: U.S. Geological Survey Misc-Invest. Map 2291-B, Scale 1:1000000.

Luedke, R.G., and Smith, R.L., 1981, Map showing distribution, composition, and age of late Cenozoic volcanic centers in California and Nevada: U.S. Geological Survey Misc-Invest. Map 1091-C, Scale 1:1000000. 
Luedke, R.G., and Smith, R.L., 1982, Map showing distribution, composition, and age of late Cenozoic volcanic centers in Oregon and Washington: U.S. Geological Survey Misc-Invest. Map 1091-D, Scale 1:1000000.

Machette, M.N., Personius, S.F., Kelson, K.I., Haller, K.M., and Dart, R.L., 1998, Map and database of Quaternary faults and folds in New Mexico: U.S. Geological Survey Open-File Report 98-521, Scale 1:750000.

McCurry, M., 1982, The geology of a late Miocene silicic volcanic center in the Woods and Hackberry Mountains area of the eastern Mojave Desert, San Bernadino County, California: Mesozoic-Cenozoic tectonic evolution of the Colorado River region, California, Arizona, and Nevada (Anderson-Hamilton volume), Cordilleran Publishers, p. 433-440.

Nakata, J.K., Wentworth, C.M., and Machette, M.N., 1982, Quaternary fault map of the Basin and Range and Rio Grande Rift province, western United States: U.S. Geological Survey Open-File Report 82-579, Scale 1:2500000.

Pearthree, P.A., 1999, Quaternary fault data and map of Arizona: Arizona Geological Survey Open-File Report 98-24, Scale 1:750000.

Saucedo, G.J., Bedford, D.R., Raines, G.L., Miller, R.J., and Wentworth, C.M., 2000, GIS data for the geologic map of California (version 2.0): California Department of Mines and Geology, 2000-007 (CD-ROM), Scale 1:750000.

Stewart, J.H., Carlson, J.E., Raines, G.L., Connors, K.A., Moyer, L.A., and Miller, R.J., 2003, Spatial database for the geologic map of Nevada: U.S. Geological Survey OpenFile Report 03-XXX, Scale 1:500000.

Stewart, J.H., and 19 additional co-authors, 1998, Map showing Cenozoic tilt domains and associated structural features, western North America (Plate 1): Geological Society of America Special Paper 323, Scale 1:5000000.

Thorson, J.P., 1971, Igneous petrology of the Oatman district, Mohave county, AZ: P. $\mathrm{hD}$. Thesis, University of California Santa Barbara.

Walker, G.W., and MacLeod, N.S., 1991, Geologic map of Oregon: U.S. Geological Survey, Scale 1:500000. 


\section{Appendix. Geologic units from the digital state geologic maps used to develop Hydrogeologic units}

The following is a list of the geologic units for each state that have been categorized into one of nine "hydrogeologic" units. Please note that the hydrogeologic unit names used here are those designated for the digital Arc/Info coverage- swlithologyc. See the pamphlet describing the scientific content of OFR 03-294 for more details on each of the nine units. Each hydrogeologic unit is also shown in map form on sheets 2 through 10 in the digital plotfiles.

Hydrogeologic unit defined in the Arc/Info digital coverage- swlithologyc

Uncosolidated alluvial deposits

Older basin fill (sandstone,conglomerate)

Older basin fill (mudstone,evaporite)

Cenozoic basalt

Cenozoic and Mesozoic non-basaltic volcanic rocks or Cenozoic non-basaltic rocks

Crystalline rocks (metamorphic,plutonic)

Pre-Cenozoic rocks (sandstone, conglomerate)

Pre-Cenozoic rocks (chert,siltstone mudstone) or Pre-Cenozoic (chert, siltstone,mudstone,evaporite)

Cenozoic and Pre-Cenozoic carbonate

rocks or Pre-Cenozoic carbonate rocks

Arizona geologic map units

(Hirschberg and Pitts, 2000)

Qy, Q, Qo

Tsy, Tsm, Tsv, Tss, Tso

QTb, Tby, Tb

Tvy, Tv, Kv, Jv, QTv

Kmv, Ks, KJs, Jm, Js, Jy, Trcs, $\mathrm{Jgc}, \mathrm{Jsv}$

Trc, Trm, Ys

Pz, P, PP, MC
Corresponding description in OFR03-294 and map sheet number in the digital plotfiles

Unconsoldated alluvial deposits (sheet 2)

Older basin- fill deposits, coarse to finegrained (Sheet 3 )

Older basin- fill deposits, fine-grained

(Sheet 4)

Cenozoic basaltic rocks (sheet 5)

Cenozoic andesite, dacite, and rhyolitic, rocks (Sheet 6)

Crystalline rocks (Sheet 7)

Siliceous sedimentary rocks, coarse-grained (Sheet 8)

Siliceous sedimentary rocks, fine-grained (Sheet 9)

Carbonate rocks (Sheet 10)

Hydrogeologic unit (this publication)

Unconsolidated alluvial deposits

Older basin fill (sandstone,conglomerate)

Cenozoic basalt

Cenozoic and Mesozoic non-basaltic

volcanic rocks

Pre-Cenozoic rocks (sandstone, conglomerate)

Pre-Cenozoic rocks (chert,siltstone, mudstone)

Cenozoic and pre-Cenozoic carbonate rocks 
Ti, Tg, TKgm, TKg, Jg, Trv, Mzo, $\mathrm{MzPz}, \mathrm{Yd}, \mathrm{Yg}, \mathrm{YXg}, \mathrm{Xg}, \mathrm{Xm}, \mathrm{Xms}$, $\mathrm{Xmv}, \mathrm{Xq}$

California geologic map units (Saucedo and others, 2000)

Q, Qg, Qls, Qs

Tc, QPc

Qrv, Qv, Qv?, Tv

Qrvp, Qvp, Qvp?, Tvp

E, E-Ep, Ep, K, K?, KJf, KJfm, Ku, $\mathrm{Ku}$ ?, Ku-Ep, M, M?, Mc, O, Oc, $\mathrm{P}$

Oc?, Pm, TK, Ec

$\mathrm{J}, \mathrm{J}$, K1, K1?, Tr

C, Ca, D, ls, Pz, SO

gb, gr, grCz, gr-m, grMz, grMz?, grpC, grpC?, grPz, KJfs, m, MtKJfs, mv, Mzv, pC, pCc, Pzv, sch, Ti, um, grCz?

Colorado geologic map units

NOTE: this is only a partial list

(Green, 1992)

Qa, Qg, Qe, Qgo, Qeo, Qd, QTa, Tgv,

Qdo, Q1

QTsa, To, Ta, Twr, Th, Tcu, Tpc, Ts,

Te, Tos, Tsp, Td

Qb, Tbb, Tbbi

Tlp, Tbr, Tbrt, Taf, Tial, Tpl, Tiql, Tmi

TKr, TKa, Kvt, Kpcl, Kpg, KJde, KJdm, @Ps, \&m, \&mb, \&b, Do

$\mathrm{Km}, \& \mathrm{mbe}$

MDO, Or

YXg, Xg, Yg, Xq, Xfh, Xm, Xb, TKi

Idaho geologic map units

(Johnson and Raines, 1995)

Qa, Qpa, Qg, Qpg, Qpug, Qpmg, Qplg,

Qpc, Qpt, Qd, Qpd, Qw, Qrw, Qpw, Qs,
Crystalline rocks (metamorphic,plutonic)

Hydrogeologic unit

(this publication)

Unconsolidated alluvial deposits

Older basin fill (sandstone,conglomerate)

Cenozoic basalt

Cenozoic and Mesozoic non-basaltic

volcanic rocks

Pre-Cenozoic rocks (sandstone,

conglomerate)

Pre-Cenozoic rocks (chert,siltstone, mudstone)

Cenozoic and pre-Cenozoic carbonate rocks

Crystalline rocks (metamorphic,plutonic)

Hydrogeologic unit

(this publication)

Unconsolidated alluvial deposits

Older basin fill (sandstone,conglomerate)

Cenozoic basalt

Cenozoic non-basaltic volcanic rocks

Pre-Cenozoic rocks (sandstone, conglomerate)

Pre-Cenozoic rocks (chert,siltstone, mudstone,evaporite)

Pre-Cenozoic carbonate rocks

Crystalline rocks (metamorphic,plutonic)

Hydrogeologic unit

(this publication)

Unconsolidated alluvial deposits 
QTg, QTs, Qp?g, Qpmd

Td, Tpd, Tmd, Ted, TKg

Qrb, Qpub, Qpm, QTb, Tpb, Tmb, Tm3b,

Tm2b, Tm1b, Qpu?b, Tm?b, Qpulb,

Qpu2b, Qpu3b, Qpu4b, Zib

Qpuf, Qpu3f, Qpu2f, Qpu1f, Qpmf,

Qpm1f, QTf, Tpf, Tmf, Tpv, Tov, Tev,

Qplf, Qpm?f, Qpmb, Qpu?f, Qpm2f

Jw, J, J1, TR, TRv, PZu, PPc, Ps, Mc,

SOc, Zn, Zs, Z1s, Y4n, Y, Y4s, Y3s,

Y2s, Y1s, TrPv, Jwm, Y?s, Ys, Z?s, Y?nm,

PNs,PPNc, Pv

$\mathrm{Kl}$, Ju, TRu, P, PPs, Dc, DSc, Cc, Cmn,

Y2n, Y1n, Y4m, Y?n, Y1nm, Y2nm,

PPNs

Ku, TRuw, TRl, PM, M, Ms, MD, PZl, D, Cenozoic and pre-Cenozoic carbonate rocks

DS, DO, S, SO, O, Ou, Ol, OCc, C, Cun,

Z2s, Y3n, Y3nm, PNM

Ti, Tmi, Ki, KJi, JTRi, pKi, Zi, PCi, P2, OC, Y, Y2m, PC, PC3, PC2, PC1, X, Km, mig, Ki?, Kif, Kii, Kim, PCim, pKim,

PZm, Tei, OCm

Nevada geologic map units

(Stewart and others, 2003)

Qa, Qls, Qm, QToa, Qp, Qmi

Tbg, Tbr, Ts1, Ts3, Tts

QTs

QTb, Tb, Tba, Tob

QTa, QTr, Ta1, Ta2, Ta3, Tr1, Tr2,

Tr3, TRk, TRPv, Trt, Tt1, Tt2, Tt3,

TRPvs

Ch, Css, CZq, Jd, JPu, JTRa, Jv, PPa,

TKs, Se

Csc, Tr, CZs, DCsv, Dsl, Dt, JTRs, Ks, MDmc, MDs, Msv, Os, Osv, Ot, PMh,

Psc, PZsp, Ss, TRch, TRPd, Ct, JTRsv,

Ds

TRc, TRPs, PPcd, Pc, PMc, PPc, Pc, $\mathrm{Mc}, \mathrm{Dc}, \mathrm{DCc}, \mathrm{Sc}, \mathrm{Oc}, \mathrm{OCc}, \mathrm{Cc}, \mathrm{SOc}$, Pcd, Ths, TKsu, Ts2, Ml, St, TRmt Jgb, TJgr, Tgr, MZgr, Kgr, KJd, Jgr, KJim, Ygr, Xm, Oct, Ti, TRgr, Tmi, Tri, Zqs, Zw, TRlgr
Older basin fill (sandstone,conglomerate)

Cenozoic basalt

Cenozoic non-basaltic volcanic rocks

Pre-Cenozoic rocks (sandstone, conglomerate)

Pre-Cenozoic rocks (chert,siltstone, mudstone)

Crystalline rocks (metamorphic,plutonic)

Hydrogeologic unit (this publication)

Unconsolidated alluvial deposits

Older basin fill (sandstone,conglomerate)

Older basin fill (mudstone,evaporite)

Cenozoic basalt

Cenozoic non-basaltic volcanic rocks

Pre-Cenozoic rocks (sandstone, conglomerate)

Pre-Cenozoic rocks (chert,siltstone, mudstone)

Cenozoic and pre-Cenozoic carbonate rocks

Crystalline rocks (metamorphic,plutonic) 
New Mexico geologic map units

(Anderson and Jones, 1997)

Qa, Q1, Qe, Qeg, Qd, Qp, ds, Qe/Qp,

Qe/Qa, Qpl, Playa, Qe/Qpl

Qoa, QTa, QTp, QTg, QTsf, QTs, Tfl,

Tsf, To, Tlp, Tc, Tps, Tsj, Tn, Toa, Tpc,

TKr, TKpr, TKa, Qp/QTs, Qa/QTs,

Qa/QTsf, Qe/QTsf, Qp/QTsf, Q1/QTs,

Qe/QTs, Qba/To, Qe/Tnb, Qp/Tsf,

Qoa/To

QTt, Tus

Qb, Qv, Qbo, QTbl, Tnb, Tpb, Tuau,

Tual, Thb, Tmb

Qr, Qvr, Qbt, Tos, Tnr, Tnv, Tv, Tlv,

Turp, Tlrp, Turf, Tlrf, Tla, TKav, Ka, Tuv

$\mathrm{Ku}, \mathrm{Kmc}, \mathrm{KTv}, \mathrm{K}, \mathrm{Kpc}, \mathrm{Kg}, \mathrm{Kmg}$, Kpg,

Kth, Kma, Kdr, Kd, Kdg, Kl, J, Jm,

Jmsu, Jz, Jze, Je, Jsr, @, Pz, \&, Pqm,

Pr, Pbc, Pcc, Pbrc, Pg, Pa, Pau, Pal, Pys,

$\mathrm{Pct}, \mathrm{Pb}, \mathrm{P} \& \mathrm{sc}, \mathrm{P} \&$, \&s, \&ps, M, MD, M,

D, SO, SOC, O_, Y, Ys, Pqr, Kcc, Pay,

Kvt, \&lc

Kkf, Kls, Kpn, Kmv, Kch, Klv, Kpl,

$\mathrm{Kms}$, Kph, Kmm, Kmr, Km, Kmu, Kml,

Kdm, Kgc, Kc, Kgg, Kgr, Kbm, @r, @b, @t,@g,@s,@cu,@m, Psl,Pc, Pat, Pco, @rp,@c

Knf, Kmf, Kgh, Pty, Pgq, Pcp, Pdm, Psa, Psg, Pvp, Ph, \&m, \&me, Mk, Psr, Py

Tif, Ti, Tui, Tuim, Tli, TKi, Ki, O_p, Yi, Yp, YXp, X, Xms, Xm, Xp, Xmo, Xmu,

$\mathrm{Zi}$

Oregon geologic map units

(Walker and MacLeod, 1991)

Qal, Qd, Qls, Qma, Qmp, Qgs, Qf, Qg, Qgf, Qt, QTg, QTst, Ql, QTs, Qs, Qpl,

Tlf

Ts, Tmsm, Tcss, Tn, Tsfj, Tm, Tms, Ty, Tt, Tmst, Tvq, Ta, Tsd, Tco, Ttvm, Tss,

Tmss, Tmsc, Tsm, Tfc, Tfee, Tyq

QTba, Tc, Tcw, Tcg, Tpb, Ttv, Tsr, Tim,

Ti, Tig, Qba, QTp, QTmv, QTa, Trb, Tmv,
Hydrogeologic unit

(this publication)

Unconsolidated alluvial deposits

Older basin fill (sandstone,conglomerate)

Older basin fill (mudstone,evaporite)

Cenozoic basalt

Cenozoic non-basaltic volcanic rocks

Pre-Cenozoic rocks (sandstone, conglomerate)

Pre-Cenozoic rocks (chert,siltstone, mudstone)

Cenozoic and pre-Cenozoic carbonate rocks

Crystalline rocks (metamorphic,plutonic)
Hydrogeologic unit (this publication)

Unconsolidated alluvial deposits

Older basin fill (sandstone,conglomerate) 
Tfe, Tbaa, Tub, Tfeb, QTib, Tib, Qyb, Qlb, Qb, QTps, QTvm, QTb, Tob, Tstv, Tvm, Tp, Tps, Tb, Tcs, Tcp, Tci, Tba, Tbas,

Tsff, Tca, Tvi, Tc?

Qa, Tsv, Tut, QTvs, Tvs, Tat, Trh, Twt, Cenozoic non-basaltic volcanic rocks

Tts, Tr, Tsf, Tas, Tct

Kc, KJds, KJm, Tu, Tus, Tsm, Tfc, Tfcc, Pre-Cenozoic rocks (sandstone, Ks, Js, JTRsv, Jub, TRsv, TRs, TRv, conglomerate)

TrPzs, Jub, TRPv, Jv

Jop, Jss, Js, Jm, cm, cs, TRPzm, TRPzs,

JTRs, mr, Psv, KJdv, Ju, TRPzu

TRPzsn, Pzs

Pre-Cenozoic rocks (chert,siltstone,

mudstone)

Cenozoic and pre-Cenozoic carbonate rocks

bc, mc, Tia, KJg, KJgu, JTRgd, Qrd, Thi, Crystalline rocks (metamorphic,plutonic)

TRPzsv, Pzsv, KJi, Jc, TRPzg

Utah geologic map units

(Hintze and others, 2000)

Qa, Qe, Qg, Qls, QT, Q1, Qs, Qao, playa

T1, T2, T3, T4, T5, TK

Qm

$\mathrm{Qb}, \mathrm{Tpb}$

Qr, Tma, Tmb, Tmr, Tmv, Tov, Tpr, Tvu

$\mathrm{JTr}, \mathrm{K} 1, \mathrm{~K} 2$, K3, P1, Jg

J1, J2, M3, Tr1, Tr2

C2, C3, D, M1, M2, O, P, P2, PeP, S, PP

Cf, Ji, PCi, PCm, PCs, Ti, C1
Hydrogeologic unit

(this publication)

Unconsolidated alluvial deposits

Older basin fill (sandstone,conglomerate)

Older basin fill (mudstone,evaporite)

Cenozoic basalt

Cenozoic non-basaltic volcanic rocks

Pre-Cenozoic rocks (sandstone,

conglomerate)

Pre-Cenozoic rocks (chert,siltstone,

mudstone)

Pre-Cenozoic carbonate rocks

Crystalline rocks (metamorphic,plutonic) 